\title{
LATE HOLOCENE LANDSCAPE EVOLUTION IN THE DAZZLER RANGE: NEW EVIDENCE
}

\author{
by Kevin Kiernan
}

(with one table and two text-figures)

\begin{abstract}
Kiernan, K., 2001 (31:xii): Late Holocene landscape evolution in the Dazzler Range: New evidence. Pap. Proc. R. Soc. Tasm. 135: 15-20. https://doi.org/10.26749/rstpp.135.15 ISSN 0080-4703. Forest Practices Board, 30 Patrick Street, Hobart, Tasmania, Australia 7000 .
\end{abstract}

Radiocarbon dating of a wood sample from the upper part of a sequence of coarse fluvial gravels at Branchs Creek has confirmed that accumulation of coarse fluvial gravels continued into the late Mid Holocene, prior to an influx of up to $3 \mathrm{~m}$ of sand during the last two millenia. Ongoing erosion at Branchs Creek has revealed that clay previously interpreted as a separate unit beneath the gravels is merely a clay lens and that the gravel/clay sequence is over $3.5 \mathrm{~m}$ thick. Investigation of a site at Saxons Creek, at the southern end of the Dazzler Range, has revealed a similar stratigraphy and confirms widespread catchment instability during the Mid to Late Holocene. The upper gravels are again rich in logs and smaller wood fragments, and two samples have returned radiocarbon ages of -4.1 and $2.2 \mathrm{ka} \mathrm{BP}$. At least $3 \mathrm{~m}$ of sand has accumulated since deposition of the gravels ceased, with at least $1 \mathrm{~m}$ of sand deposited over the last several centuries. As at Branchs Creek and elsewhere in the Dazzler Range, pronounced incision into alluvial sediments has been triggered by artificial straightening of the Saxons Creek channel.

Key Words: Tasmania, Dazzler Range, radiocarbon dating, fluvial geomorphology, climate change, slope stability, channel stability, land management.

\section{INTRODUCTION}

Radiocarbon daring of wood and charcoal from alluvial sediments on the flanks of the Dazzler Range in northern Tasmania (fig. 1) indicated that deposition occurred during the Mid to Late Holocene, 5.2-1.8 kyr BP (Kiernan 1998). Coarse gravels in the earliest deposits were suggested to have been recycled from relict periglacial gravels in response to increased runoff and channel instability, brought about by neoglacial cooling coupled with changes in vegetation structure and associated fire frequency. The aggradation of finer sediment appears to have occurred over the last two millenia. The dating of the gravels rested on a single radiocarbon age of $5220 \pm 80{ }^{14} \mathrm{C}$ yr BP (Beta 44279) for a wood sample from within the upper part of the gravels at Branchs Creek on the western flanks of the Dazzler Range (Tamar 1:25 000 sheet 8215-690393). The dating of the later sandy alluvial sediments rested on two radiocarbon results from Branchs Creek, and a further radiocarbon date from Massey Creek on the lowermost eastern flanks of the range (8215-795438).

The aims of the present study were (1) to confirm the age of the coarse gravels at Branchs Creek; (2) to revisit the stratigraphy of Branchs Creek in the light of new exposures revealed by ongoing erosion; and (3) to investigate a further sequence of wood-bearing alluvial sediments at Saxons Creek on the southern margin of the Dazzler Range.

\section{NEW EVIDENCE}

\section{Branchs Creek}

The Branchs Creek section occurs at $-15-25 \mathrm{~m}$ altitude at the head of a small alluvial fan that has probably been constructed over an old shoreline of Last Interglacial age. Deep gullying of the alluvial deposits has revealed coarse fluvial gravels buried deeply beneath fluvial sands. Three alluvial units were recognised in the original research at
Branchs Creek. Unit Br 1, the uppermost, comprised up to $3 \mathrm{~m}$ of sands with weakly developed palaeosols (Kiernan 1998, fig. 2C); unit Br 2 comprised a bed of coarse gravels at least $2 \mathrm{~m}$ thick; and unit $\mathrm{Br} 3$ consisted of basal dense clay.

In order to test the earlier dating of the gravels, a further wood sample from Unit $\mathrm{Br} 2$ just upstream from site $\mathrm{D}$ at Branchs Creek was collected in July 1998. This sample was obtained from a section $2.9 \mathrm{~m}$ high comprising $1.4 \mathrm{~m}$ of coarse (Unit $\mathrm{Br}$ 2) gravels overlain by $1.5 \mathrm{~m}$ of sand (Unit $\mathrm{Br}$ ) (fig. 2, Branchs $\mathrm{Ck} \mathrm{A}$ ). The dated sample was obtained from a large log at $0.8 \mathrm{~m}$ depth in the gravels; it returned an age of $4820 \pm 70{ }^{14} \mathrm{C}$ yr BP (Beta 120239) (table 1).

Further fluvial incision of the sequence since the original study has shown that what was defined as unit $\mathrm{Br} 3$ is, in fact, merely a sandy-clay lens within Unit $\mathrm{Br} 2$, which continues to a depth of at least $0.5 \mathrm{~m}$ beneath the lens. The revised stratigraphy presented in figure 2 (Branchs $\mathrm{Ck} B$ ) supersedes that depicted by Kiernan (1998, fig. 2, column A). The gravel sequence that contains the sand lens is at least $3.5 \mathrm{~m}$ thick.

\section{Saxons Creek}

Saxons Creek drains a low ridge at the southern end of the Dazzler Range, and discharges ultimately into the southeastern arm of Port Sorell via Franklin Rivulet. Its catchment is slightly larger, lower and less steep than that of Branchs Creek, with which it shares a drainage divide ranging from $520 \mathrm{~m}$ to $215 \mathrm{~m}$ altitude. As at Branchs Creek and Massey Creek, channel straightening associated with land development for agriculture has increased the erosive capacity of the flow relative to that through the original, unmodified channel, and facilitated pronounced gullying (Kiernan 1999).

An alluvial fan originates at $-110 \mathrm{~m}$ altitude and has accumulated on a small plain perched upstream from a structural ridge. The recently eroded gully commences at $-105 \mathrm{~m}$ altitude (GR736313), revealing moderately 


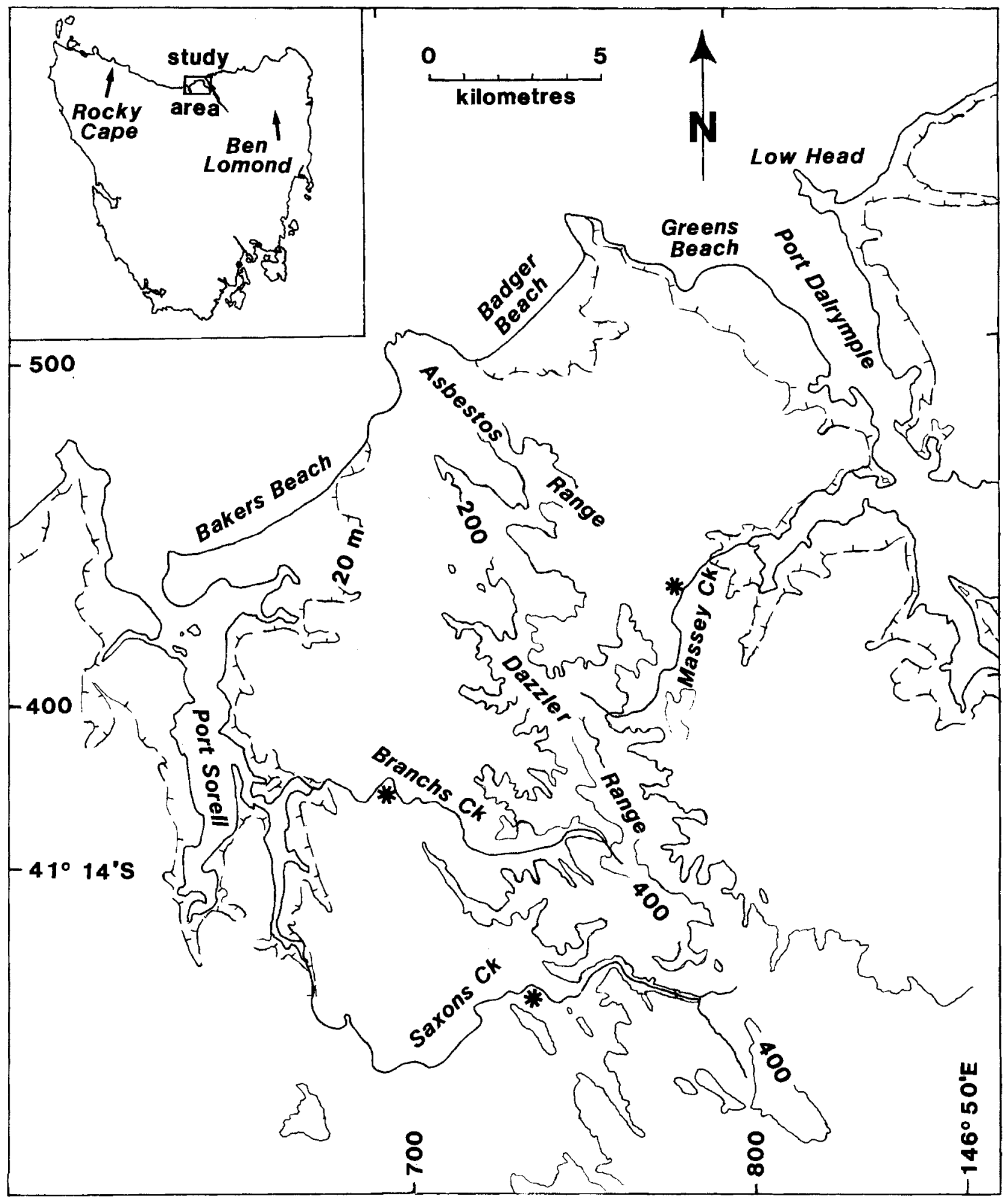

FIG. 1 - Location of the study area. Dated sections are indicated by asterisks. 


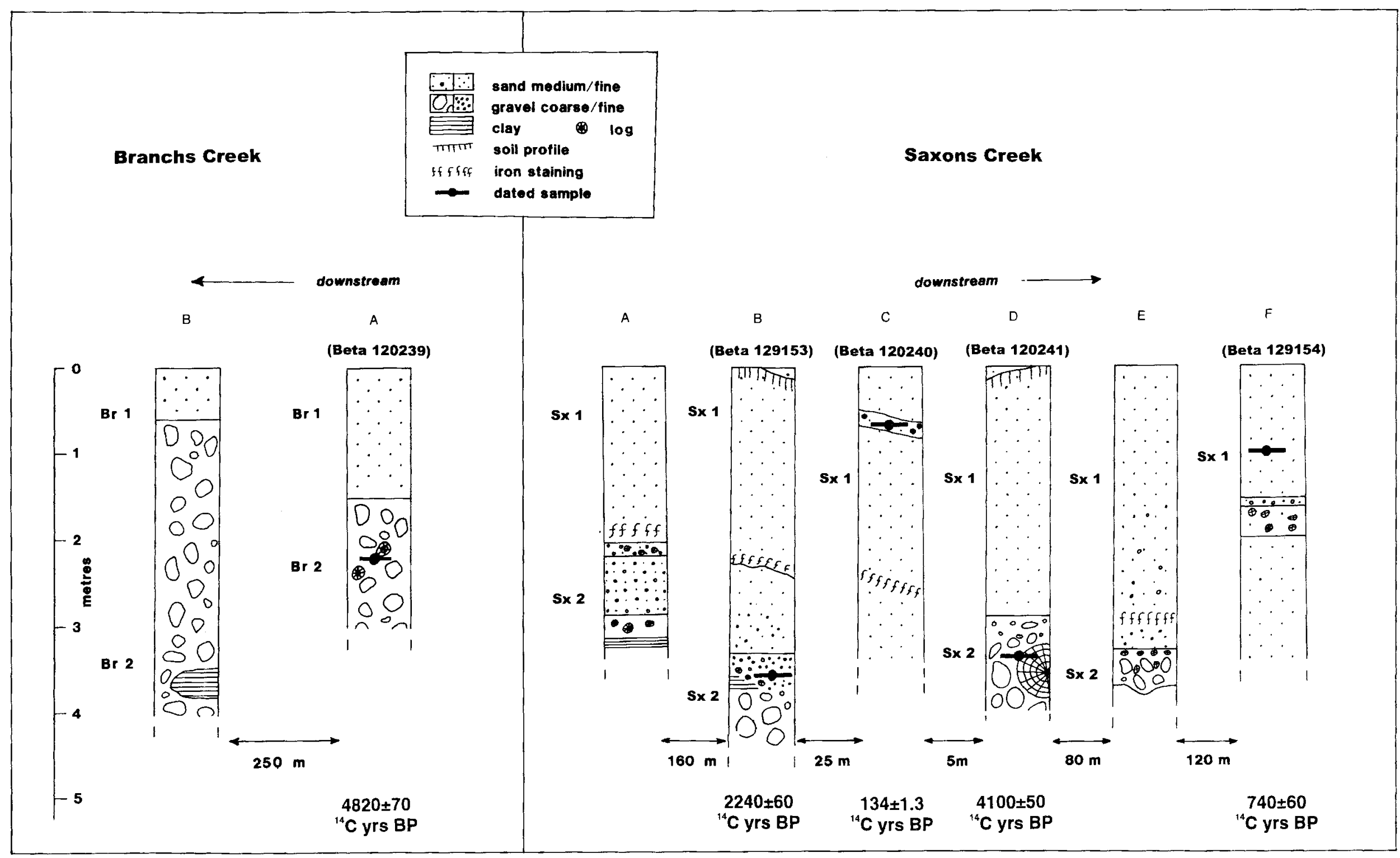

FIG. 2 - Sections through the sediments at Branchs Creek and Saxons Creek. Branchs Creek B supersedes that depicted by Kiernan 1998 (fig. 2, column A), following deeper fluvial incision and exposure of the sequence. 
rounded to well-rounded, low-sphericity coarse gravels at least $2 \mathrm{~m}$ thick (Unit $S \times 2$ ) overlain by at least $3.5 \mathrm{~m}$ of sand (Unit Sx 1) (fig. 2, Saxons Ck A-F). The stratigraphy of the Quaternary sediments is essentially identical to that previously described from Branchs Creek and Massey Creek (Kiernan 1998).

On the true left bank of the gully, $-200 \mathrm{~m}$ from its origin, $-3.5 \mathrm{~m}$ of sand overlies at least $2 \mathrm{~m}$ of gravel (Unit $S \mathrm{x} 2)$ that is generally coarse $(\max .-0.8 \mathrm{~m}$, mean $<0.4 \mathrm{~m}$ ) but becomes finer (max. $-0.4 \mathrm{~m}$, mean $<0.1 \mathrm{~m}$ ) within $0.5 \mathrm{~m}$ from the top of the unit (fig. 2, Saxons Ck D). A large $\log$ nearly $1 \mathrm{~m}$ in diameter occurs in the zone of transitional gravel thickness. Radiocarbon dating of a sample from the outer surface of this log produced an age of 4100 $\pm 50{ }^{14} \mathrm{C}$ yr BP (Beta 120241) (table 1). Further upstream, Unit $S_{x} 1$ sands $-3 \mathrm{~m}$ thick overlie $0.4 \mathrm{~m}$ of fine gravels beneath which are coarse gravels (fig. 2, Saxons Ck B). Radiocarbon dating of the outer part of a small log at $0-0.1 \mathrm{~m}$ depth in the gravels has given an age of $2240 \pm 60$ ${ }^{14} \mathrm{C}$ yr BP (Beta 129153).

At both these sites the Unit $S_{x} 1$ sand exhibits a mottled zone $0.2-0.3 \mathrm{~m}$ thick in its central part. A shallow channel $-1 \mathrm{~m}$ deep occurs in the surface of Unit Sx 1 and is floored by $0.3-0.4 \mathrm{~m}$ of fine gravels containing small wood fragments. The channel is partly filled by $0.5-0.6 \mathrm{~m}$ of sand (fig. 2, Saxons $\mathrm{Ck}$ C). Radiocarbon dating of a wood fragment from the gravels on the floor of this channel gave an age of $134 \pm 1.3^{14} \mathrm{C}$ yr BP (Beta 120240), implying that the wood is modern.

A few hundred metres further downstream, still on the true left, organic materials are more abundant in the Unit Sx 1 sediments (fig. 2, Saxons Ck F). Here, $2 \mathrm{~m}$ of mediumfine sand overlies $0.2 \mathrm{~m}$ of gritty sand, a woody bed $30-70 \mathrm{~mm}$ thick comprising small twigs and branches, and beneath it clayey sand with a blocky structure. The basal clays here are interpreted as stillwater deposits and the woody bed as material washed into a topographic lowpoint. Carbonised wood fragments from $1 \mathrm{~m}$ depth in the sand gave a radiocarbon age of $740 \pm 60{ }^{14} \mathrm{C}$ yr BP (Beta 129154).

\section{DISCUSSION}

The radiocarbon result of $4820 \pm 70{ }^{14} \mathrm{C}$ yr BP (Beta 120239) for the new wood sample from the Unit $\mathrm{Br} 2$ gravels at Branchs Creek strengthens the evidence for significant Mid Holocene instability in this catchment. This result is within two standard deviations of the original age of 5220 $\pm 80{ }^{14} \mathrm{C}$ yr BP (Beta 44279) obtained from the same site. The slightly younger ${ }^{14} \mathrm{C}$ age of $4100 \pm 50 \mathrm{yr}$ BP (Beta 120241) from the large log at Saxons Creek is consistent with the caution expressed previously that logs slightly older than the gravel may have become incorporated within it.

The discovery that the clay unit originally defined as Unit $\mathrm{Br} 3$ is merely a lens within the $\mathrm{Br} 2$ gravels rather than a distinct unit means there is no evidence for an earlier phase of only fine sediment aggradation. The possibility that the "basal clay" (Unit M3), previously described from Massey Creek on the eastern side of the range, might also be merely a lens within the gravels that overlie it in the exposure (Kiernan 1998, fig. 2, column G) must also be acknowledged. Hence, there is no compelling evidence for any period of stability between the Last Glacial Maximum (LGM) and deposition of the coarse gravels so that an entirely Holocene age for the gravels cannot be confirmed. However, the radiocarbon ages obtained from the abundant logs and other woody debris within the upper part of the gravels still implies significant catchment instability and gravel mobilisation in the late Mid Holocene.

There are striking similarities between the broad stratigraphic sequence at Saxons Creek and the section previously described from Branchs Creek, although the dating at Saxons Creek raises further questions. The radiocarbon age of $4100 \pm 50{ }^{14} \mathrm{C}$ yr BP (Beta 120241) obtained from the outer part of a large log in the Unit $S \times 2$ gravels at Saxons Creek is broadly consistent with the ages obtained from Branchs Creek, though it might suggest gravel deposition occurred slightly later. However, the very much younger age of $2240 \pm 60{ }^{14} \mathrm{C}$ yr BP (Beta 129153), obtained from another log in a similar stratigraphic context only 20-30 m distant in the same section at Saxons Creek,

TABLE 1

New radiocarbon dates from the Dazzler Range

\begin{tabular}{lccc}
\hline Sample no. & Laboratory no. & Sample depth $(\mathrm{m})$ & Age $\left({ }^{14} \mathrm{C}\right.$ yr BP) \\
\hline $\begin{array}{l}\text { Saxons Creek } \\
\text { SAX-04 }\end{array}$ & Beta 120240 & 0.6 & $134 \pm 1.3$ \\
SAX-12 & Beta 129154 & 1.0 & $740 \pm 60$ \\
SAX-03 & Beta 129153 & 3.6 & $2240 \pm 60$ \\
SAX-06 & Beta 120241 & 3.5 & $4100 \pm 50$ \\
$\begin{array}{l}\text { Branchs Creek } \\
\text { BRA 98/3 }\end{array}$ & Beta 120239 & & \\
\hline
\end{tabular}


is problematic. This single, appreciably younger age from the finer upper part of these gravels may be explicable by reworking of the gravel surface or by contamination through younger humic acid moving down through the sediment profile, as suggested by the iron mobilisation (fig. 2). However, this date compares with the age of $2580 \pm 130$ ${ }^{14} \mathrm{C}$ yr BP (Beta 44275) previously obtained on charcoal and wood fragments from $2.2 \mathrm{~m}$ depth beneath a thin bed of fine gravel in the sands at Massey Creek, and raises the possibility of ongoing deposition of wood-bearing gravels later than was originally envisaged.

The radiocarbon result of $740 \pm 60{ }^{14} \mathrm{C}$ yr BP (Beta 129154), obtained from carbonised wood fragments at $1 \mathrm{~m}$ depth at site $\mathrm{D}$ at Saxons Creek, is significantly younger than the ages obtained from similar depths in the Unit $\mathrm{Br} 1$ sands at Branchs Creek ( $\sim 1.8 \mathrm{ka} \mathrm{BP}$ and $\sim 1.9 \mathrm{ka} \mathrm{BP})$. Some of the differences in age of the coarser and finer alluvial units in different locations throughout the Dazzler Range may be due to intrinsic factors, such as geomorphic responses and response times caused by catchment and topographic differences. The carbonised wood sample from Saxons Creek was obtained towards the distal edge of the alluvial fan, $800 \mathrm{~m}$ downstream from the point at which that stream emerges from its valley onto a small, structurally perched plain. The Saxons Creek catchment is slightly larger but less steep than that of Branchs Creek. In contrast, the dated samples from Unit Br 1 at Branchs Creek were obtained from relatively high up the the alluvial fan deposited by that stream where the valley is still relatively narrow $(-250 \mathrm{~m})$ and where a small, steep tributary joins the main stream. Overbank flow at Branchs Creek has been confined upstream of the main fan and this, together with the steeper gradient, is likely to have resulted in occasional erosion of upper horizons. The gentler gradient and less confined setting of the Saxons Creek site is more favourable for the accumulation and preservation of flood debris. This interpretation is consistent with the earlier assumption (Kiernan 1998) of ongoing fan accretion well after $1.8 \mathrm{ka}$ BP. At least $3.5 \mathrm{~m}$ of sand has accumulated since $-2.2 \mathrm{ka}$ $\mathrm{BP}$, with over $1 \mathrm{~m}$ of accretion since $0.7 \mathrm{ka} \mathrm{BP}$. These figures would imply accretion at a mean rate of 1.3-1.6 $\mathrm{mm} / \mathrm{a}$ if sand deposition were continuous. However, the presence of weakly developed palaeosols within the sands at Branchs Creek (Kiernan 1998, fig. 2C) implies that periods of stability intervened.

The transition from sand accumulation to the deep incision of the previously accumulated sediments occurred well after $740 \mathrm{yr}$ BP. The very straight trajectory of the Saxons Creek channel suggests it has been artificially modified, and gullying subsequent to channel straightening would be consistent with the known triggers of the erosion at Branchs Creek and Massey Creek. The shallow, buried channel in the surface of the sands at Saxons Creek (fig. 2X) is interpreted as a remnant of the natural drainage system that existed on the plain prior to European settlement. The modern ${ }^{14} \mathrm{C}$ age (134 a) from the floor of this channel is consistent with the thesis of relative channel stability prior to European settlement and artificial canalisation of the water flow.

The new evidence from Saxons Creek extends the evidence for widespread catchment instability in the Dazzler Range during and since the late Mid Holocene. Coarse gravels similar to those previously deposited by streams draining the Dazzler Range are no longer being deposited today. While they are similar to gravels that have commonly been attributed to periglacial slope instability, the dating indicates that at least their upper horizons considerably postdate the LGM, when periglacial processes are likely to have been significant on the low Dazzler Range. For this reason, they were previously interpreted as having been reworked from reservoirs of periglacially derived sediment that had stabilised earlier in the Holocene, but were destabilised in the late Mid Holocene (Kiernan 1998). The deeper exposure now accessible at Branchs Creek contradicts the suggestion that the coarse gravels overlie sands, previously interpreted as Early Holocene, hence an entirely Holocene age for the gravels remains unproven.

If the similarity of the stratigraphy observed at Branchs Creek, Massey Creek and Saxon Creek can be taken to imply a phase of slope instability and alluvial sedimentation that affected the entire range, which seems highly probable, then the evidence now available suggests it may be no older than $-4.1{ }^{14} \mathrm{C}$ kyr BP. This remains consistent with the earlier suggestion that neoglacial cooling coupled with changes in fire frequency may have been involved. Speleothem evidence from Lynds Cave at Mole Creek, central northern Tasmania, indicates conditions of maximum cold at $-3.8 \mathrm{kyr}$ BP (Goede \& Hitchman 1984). Palaeotemperatures calculated from speleothems from Frankombes Cave in the Florentine Valley, south-central Tasmania, suggest temperatures were $2-3^{\circ} \mathrm{C}$ colder than now at -4.1 kyr BP and nearly as low on at least four other occasions between $3.8 \mathrm{kyr} \mathrm{BP}$ and $3.0 \mathrm{kyr} \mathrm{BP}$ (Goede et al. 1990). The onset of gravel deposition in the Dazzler Range slightly predates $4.1 \mathrm{kyr} \mathrm{BP}$ and it probably terminated before $3.0 \mathrm{kyr}$ BP. Analysis of pollen from sediments at Solomons Jewel Lake in highland central northwestern Tasmania led Dodson (2001) to suggest the main vegetation type did not change over the past $4.0 \mathrm{kyr}$, but subtle changes occurred in some elements. He suggested sclerophyll vegetation remained unchanged, apart from a reduction in Eucalyptus $-3.5-3.2 \mathrm{kyr}$ BP, but a small decline in rainforest taxa began -1.7 kyr BP, followed by expansion of Sphaghum from $1.2 \mathrm{kyr}$ BP and Athrotaxis cupressoides and Cyperaceae at $0.9-0.8 \mathrm{kyr} \mathrm{BP}$, which may have been associated with cooling.

There is no evidence for any resurgence of glacial activity in Tasmania during the Holocene, consistent with the limited temperature decline that has been suggested and the present height of the theoretical snowline (Kiernan 1991). However, abundant evidence exists in the higher mountains that occur elsewhere in temperate southern latitudes. Some glaciers in the southern Andes may have readvanced from $4.7-3.3 \mathrm{ka} \mathrm{BP},>2.5 \mathrm{ka} \mathrm{BP}, 2.5-1.3 \mathrm{ka}$ $\mathrm{BP}$, and on several occasions during the last $1.2 \mathrm{ka} \mathrm{BP}$ (Clapperton 1993). Nested moraines indicate that neoglacial advances in New Zealand diminished only slightly towards the present (Birkeland 1982, Chinn 1996). The culmination of Early Neoglacial Advance in New Zealand is provisionally dated to -4.6-4.4 kyr BP (Porter 2000).

The Stanley River in western Tasmania appears to have stabilised in its present channel at $3.5-3.2 \mathrm{ka} \mathrm{BP}$, with complete stabilisation in its present channel occurring after this. Nanson et al. (1995) interpreted this as being due not to any detectable vegetation change but to a change in climate and a reduction in flow evident from a decline in channel capacity and sediment texture. The new ${ }^{14} \mathrm{C}$ dating evidence from Branchs Creek and Saxon Creek, and analogy with the evidence for recurrent cold phases at broadly equivalent southern latitudes in New Zealand and South 
America, support the evidence for catchment instability in the Dazzler Range having been driven by temperature decline, probably coupled with changes in vegetation structure and fire frequency. Since no significant decline in sea level occurred during the Late Holocene cool episodes, the floor of Bass Strait would not have been exposed and, hence, enhanced continentality would not have diminished precipitation. If the forest biomass on slopes was reduced by temperature effects but precipitation did not decline significantly, then enhanced runoff and erosion is likely to have ensued. Alternatively, significant catchment erosion is also likely to have ensued if the redevelopment of the vegetation lagged behind an increase in precipitation.

Hope (1999) suggested human impact may have been the dominant influence on vegetation change over the last 4000 years in island and mainland northwestern Tasmania. He recorded a distinct phase of highly carbonised particle accumulation in organic lagoon sediments from 4000 $2500 \mathrm{yr}$ BP at Stockyard Creek on Hunter Island, Bass Strait, associated with increased woody vegetation, that he suggested may correspond with abandonment of the island by Aborigines. Moderate to low charcoal levels thereafter may represent a more variable fire regime. Hope found only moderate levels of burning evident from similar sediments at Sundown Creek, $60 \mathrm{~km}$ further south on the west coast of mainland Tasmania, until a general increase in burning coincident with European colonisation. Similarly, Hopf et al. (2000) suggested the dominant factors responsible for Mid to Late Holocene vegetation change around Lake St Clair, west-central Tasmania, were reduced precipitation and Aboriginal burning. However, no direct evidence has been found to implicate Aborigines in the catchment instability in the Dazzler Range.

The evidence for deposition of substantial volumes of sediment during the Late Holocene emphasises the metastable condition of the Dazzler Range catchments. The dramatic decline in stability of the Saxons Creek channel following its artificial straightening as part of pasture development mirrors similar problems elsewhere around the flanks of the range and further emphasises the need for a cautious approach to land management in the area.

\section{ACKNOWLEDGEMENTS}

I am grateful to the Forest Practices Board for funding radiocarbon dating of samples, and to Nathan Duhig for helpful comments on a draft of this manuscript.

\section{REFERENCES}

Birkeland, P., 1982: Subdivision of Holocene glacial deposits, Ben Ohau Range, New Zealand, using relative dating methods. Geol. Soc. Amer. Bull. 93: 433-449.

Chinn, T.J., 1996: The southern hemisphere glacial record New Zealand and Antarctica. In Banks, M.R. \& Brown, M.J. (Eds.): CLIMATIC SUCCESSION AND GLACIAL HISTORY OF THE SOUTHERN HEMISPHERE OVER THE LAST FIVE MILLION YEARS. Pap. Proc. R. Soc. Tasm. 130(2): 17-24.

Clapperton, C., 1993: QUATERNARY GEOLOGY AND GEOMORPHOLOGYOFSOUTH AMERICA. Elsevier, Amsterdam, London, New York, Tokyo: 779 pp.

DODSON, J.K., 2001: A vegetation and fire history in a sub-alpine woodland and rain-forest region, Solomons Jewel Lake, Tasmania. Holocene 11: 111-116.

Goede, A. \& Hitchman, M.A., 1984: Late Quaternary climatic change: Evidence from a Tasmanian speleothem. In Vogel, J.C. (Ed.): LATE CAINOZOIC PALAEOCLIMATES OF THE SOUTHERN HEMISPHERE. Balkema, Rotterdam: 221-232.

Goede, A, VeeH, H.H. \& Ayliffe, L.K., 1990: Late Quaternary palacotemperature records for two Tasmanian speleothems. Aust. J. Earth Sci. 37: 267-278.

Hope, G., 1999: Vegetation and fire response to late Holocene occupation in island and mainland noth west Tasmania. Quat. Int. 59: 47-60.

Hopf, F.V.L., Colhoun, E.A. \& Barton, C.E., 2000: Lateglacial and Holocene record of vegetation and climate from Cynthia Bay, Lake St Clair, Tasmania. J. Quat. Sci. 15(7): 725-732.

Kiernan, K., 1991: Glacial history of the upper Derwent Valley, Tasmania. NZ J. Geol. Geophys. 34: 157-166.

Kiernan, K., 1998: Holocene landscape instability in the Dazzler Range, northern Tasmania. Pap. Proc. R. Soc. Tasm. 132: $35-40$.

Kiernan, K., 1999: Landscape evolution in the Dazzler Range. Forest Practices News 1(3): 15-16.

Nanson, G.C., Barbetti, M. \& Taylor, G., 1995: River stabilisation due to changing climate and vegetation during the late Quaternary in western Tasmania, Australia. Geomorphology 13: 145-158.

PORTER, S.C., 2000: Onset of neoglaciation in the Southern Hemisphere. J. Quat. Sci. 15(4): 395-408. 